\title{
CHANGES IN THE DEGREE OF GALACTOSYLATION OF RABBIT IgG DURING LONG-TERM IMMUNIZATION WITH BOVINE SERUM ALBUMIN
}

\author{
ĆIRIĆ DRAGANA and MILOŠEVIĆ-JOVČIĆ NADEŽDA
}

Institute for Medical Research, Belgrade

\author{
(Received 5. March 2004)
}

The galactose content of isolated IgG was analyzed before immunization and at intervals during prolonged immunization over 16 months. It was found that IgGs from non-immunized and immunized animals differed in galactose content and that the galactose content of serum IgG varied during the course of the immune response. These results suggest possible intraclonal variations or the emergence of subclones of cells secreting IgG that is differently galactosylated relative to the IgG of non-immunized animals. Since isotypic polymorphism of IgG (subclasses), which determines the effector potential(s) of IgG antibodies, does not exist in rabbits, glycosylation may be what defines functional subsets of isotypically uniform antibodies produced during an immune response in these animals.

Key words: IgG, galactose content, immune response

\section{INTRODUCTION}

Immunoglobulin $\mathrm{G}(\mathrm{IgG})$ is a multifunctional glycoprotein with, on average, 2.8 mol of oligosaccharides (glycans) per mol of lgG (Rademacher et al., 1996). Most of the carbohydrate moiety is present on the Fc region where complex biantennary oligosaccharides are covalently linked to the conserved Asn-297 in both $\mathrm{CH} 2$ domains. Glycosylation of the Fc region appears to be essential for the conformation of the IgG molecule (Masuda et al., 2000; Krapp et al., 2003) and, consequently, for full expression of the effector functions, such as activation of the classical complement pathway, binding to the Fc receptors on the cell surface, induction of antibody-dependent cellular cytotoxicity, rapid elimination of antigenantibody complexes from the circulation and feedback immunosuppression (Jefferis et al., 1998). Each oligosaccharide chain, attached to the Fc region is composed of a core heptasaccharide structure with variable additions of fucose (Fuc) and outer arm sugars, such as galactose (Gal), bisecting Nacetylglucosamine (GlcNAc) and sialic acid (NeuAc) (Fig 1).

The oligosaccharides attached to the Fc region are mostly neutral (without sialic acid) and are classified into three types, G0, G1 and G2, according to the number of terminal Gal residues. Additional heterogeneity results from the presence or absence of Fuc and/or bisecting GlcNAc, such that one of 16 different neutral, asialoglycans may be attached at the Asn-297 residue (Rademacher et 
al., 1996). Therefore, IgG can be regarded as a population of glycosylated variants or glycoforms, each conveying different physical and biochemical properties (Wormald et al., 1997, Yamaguchi et al., 1998) which may result in functional diversity (Jefferis and Lund, 1997). The relative proportions of IgG glycoforms have been shown to alter, both in relation to and as a result of physiological changes. A shift towards a particular IgG glycoform(s) has been observed to occur in some human chronic inflammatory diseases (Youings et al., 1996; Watson et al., 1999), as well as in autoimmune prone mice (Bodman et al., 1994; Thompson et al., 1996), suggesting that the carbohydrate moiety might be involved in disease pathogenesis. Changes in the proportion of IgG glycoforms under different physiological or pathological conditions most probably reflect a shift in the distribution of specific antibodies of the IgG class during the ongoing, often chronic, humoral immune response to a given antigen. However, little is known about the dynamics of changes in the glycosylation of IgG during such a response, and particularly about the appearance of glycoforms that may be of pathogenetic relevance. So far, galactosylation changes at different time points during a normal immune response has been studied only in mice (Lastra et al., 1998).

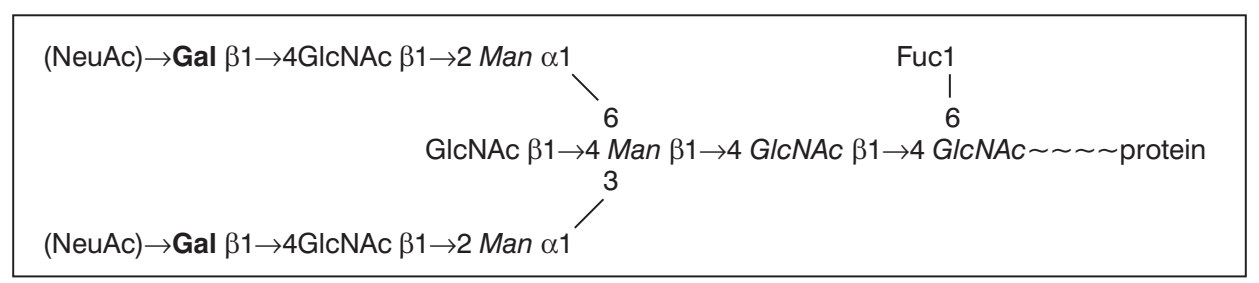

Figure 1. Structure of the N-linked oligosaccharide chain, attached to Asn-297 in the $\mathrm{CH} 2$ domain of the Fc region in the IgG molecule

This paper describes an experiment in which chronological variations in the IgG glycosylation status were analysed during long term immunization of rabbits with bovine serum albumin (BSA). The results showed that a long lasting humoral anti-BSA response is followed by permanent changes in the galactose content of serum IgG.

\section{MATERIAL AND METHODS}

Animals. The experimental model has been previously described in detail (Milošević-Jovčić et al., 1995). Briefly, ten male Chinchilla rabbits weighing 2,5-3 $\mathrm{kg}$ each were immunized with BSA (twice crystallized, Miles Laboratorie) in two phases lasting three months each. After the first phase animals had a rest period of seven months. For the first inoculation in each phase $20 \mathrm{mg}$ of albumincomplete Freund's adjuvant (FCA) mixture was administered intradermally into each animal. Further injections of $10 \mathrm{mg}$ of antigen in saline were given 
subcutaneously at various time intervals. Non- immunized rabbits served as controls. Six control animals were kept during the whole period of immunization under the same conditions as the immunized rabbits.

Serum samples used for analysis originated from blood taken by ear vein puncture on day 0 (before immunization) and at monthly intervals during the course of immunization. Serum samples were stored frozen at $-80^{\circ} \mathrm{C}$. After thawing the samples were centrifuged at $10000 \mathrm{rpm}$ before being used for IgG isolation.

$\lg G$ was isolated from pooled rabbit sera by protein $G$ chromatography. Eleven IgG samples representing the eleven different time points of prolonged immunization were prepared.

The galactosylation profile of isolated rabbit IgGs was determined by using RCA-I and GS-II lectins in a competitive lectin-binding ELISA (ELBA). They bind to galactose (Gal) and N-acetylglucosamine (GlcNAc) residues respectively when sialic acid is absent. In this assay system normal rabbit IgG (nlgG) from preimmune sera, bound to a solid phase, served as a receptor for sugar specific lectins, while solute IgG from different phases of immunization (ilgG) served as inhibiting ligands of the lectin-receptor interactions. The concentration of ilgG necessary to achieve $50 \%$ inhibition of lectin binding to immobilized nlgG was taken as the measure (KI50) of the relative abundance (expression) of accessible sugars.

\section{RESULTS}

Galactose content of isolated IgG was analysed before immunization and at intervals during prolonged immunization for 16 months. It was found that IgGs from nonimmunized and immunized animals differed in galactose content and that the galactose content of serum IgG varied during the course of the immune response (Fig 2).

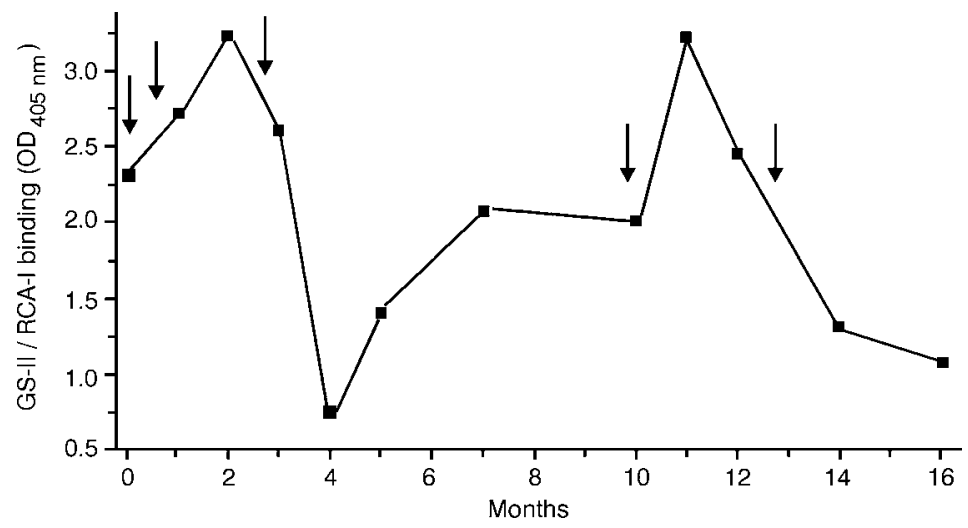

Figure 2. Change with time in the degree of galactosylation of IgG in hyperimmunized rabbits. The data are the means of all immunized animals at each time point. Arrows indicate BSA injections 
Within the first month of immunization, an increase in galactose content of serum IgG was registered. Then, between days 30 and 120 , the galactose content of serum IgG declined gradually, a 3,7-fold lower value relative to that observed for IgG before immunization. The galactose content of IgG climbed back slowly during the rest period of seven months and at 10 months approached the value registered prior to immunization. Repetitive immunization led to fluctuations in IgG galactosylation similar to those observed in the first phase. After an initial rise within the first month of the second immunization phase, the degree of IgG galactosylation fell. Somewhere about this time, up to 18 months when they were sacrificed, all rabbits showed clear clinical signs of arthritis, such are swelling and redness in all joints, and became almost completely immobilized. Histological evidence of arthritisis is however, not available, since histopathology of the joints was not examined.

\section{DISCUSSION}

Glycosylation of the Fc region of IgG is of vital importance for the full expression of the proper Fc effector functions. There are many different glycoforms of $\mathrm{IgG}$, each probably with a unique profile of effector functions. Antibodies of the IgG class are produced during the secondary immune response and the proportions of each IgG glycoform within the specific response to a given antigen could differ widely. Although differences in the functional activity of differently glycosylated IgG has been observed and pathogenicity of glycoforms devoid of galactose (G0) has been demonstrated, the dynamics of changes in carbohydrate content of IgG during the course of humoral immune responses remains largely unsolved. At present little is understood about the mechanisms that regulate changes in the glycosylation profile of IgG during immune responses.

The results of our work showed that variations in galactose content of serum IgG occurred during the humoral anti-BSA response in rabbits. A change in IgG galactose content was seen soon after the initial injection, as well as after the later boosts. In relation to IgG obtained before immunization, both increased and decreased galactose content was registered in IgG over the entire immunization period studied. However, a certain tendency of galactosylation to fluctuate in a special way was manifested. Namely, after an initial, rather rapid rise within the first month, galactose content declined gradually within the next two months, a trend shown to be similar in both phases of prolonged immunization, which lasted three months each and which were separated with a rest period of seven months. These findings are very similar to those obtained by Lastra et al. (1998) in mice immunized with BSA. The humoral anti-BSA response in their experimental model was shown to be accompanied by an initial rise and later fall in IgG galactose content. IgG antibodies became less galactosylated as anti-BSA titers increased and more galactosylated as titers fell. The authors interpreted such findings as to suggest that "at some time points and in some circumstances a decrease in IgG galactosylation can occur at the time IgG synthesis is greatest, and conversely as the rate of IgG synthesis decreases IgG galactosylation increases". The same 
could be seen in our model; the galactose content of IgG climbed slowly during the rest period of seven months and returned to the values registered prior to immunization. However, the rapid transient rise in galactose content (decrease in GO level) at the begining of immunization, seen in both models, remains unclear. It may be interesting to consider an old experiment of De Vos-Cloetens et al. (1971), who showed that immunization of rabbits with BSA or TMV stimulates concomitant synthesis of specific antibodies and immunoglobulins which are unable to react with the injected antigen but are in some way specifically related to it. The stimulation of these non-specific immunoglobulins was most marked in the early phase of either the primary or anamnestic response. The fact that serum anti-BSA antibodies in our experiment were detected in the majority of animals 15 to 18 days after antigen injection, and 5 to 10 days after antigen injection IgG had a galactose content higher than before immunization, may suggest the possibility that the population of $\lg G$ with increasing galactose content belonged to these non-specific, antigen related, immunoglobulins. In our experiment this "early" IgG with increased galactose content was detected only after the first dose of antigen which, in both immunization phases, was emulsified in FCA. Further inoculations were without FCA, and were followed by IgG with decreased galactose content (increase in G0 level) regardless, however, of the intervals of antigen injection. Although exposure to mycobacteria has been observed to result in increased serum G0 in arthritis-prone mice (Rook et al., 1991; Bodman et al., 1994), other data showed an initial fall in \%GO in mice immunized with antigen in FCA (Pilkington et al., 1996). Rapid transient lowering of \%G0, detectable in the ELISA, in the serum of mice 3-4 hours after a single injection of collagen dissolved in acetic acid and emulsified in FCA has been ascribed to the bacterial-mimetic characteristic of G0 IgG and the possible ability of some of the ingredients of the adjuvant to induce the mechanism (other than FcR binding) by which IgG terminating with GLCNAc on the Fc oligosaccharides may be removed from the circulation (Pilkington et al., 1996).

It is not clear why changes in the relative extent of galactosylation occur during the immune response. IgG galactosylation is known to be controlled by a galactosyl transferase that mediates the transfer of galactose to an acceptor, so agalactosyl IgG production has generally been ascribed to a decrease in galactosyl transferase activity of B lymphocytes (Alavi and Axford, 1996). However, our findings confirm that during the immune response the glycoform profile fluctuates, and particularly that galactosylation of specific $\lg G$ antibodies can vary independently of the total IgG galactosylation, which remains relatively constant (Lustra et al., 1998). This is suggestive of heterogeneity within the proliferative antibody-producing clone. The mechanism governing this heterogeneity is, however, not known. The fluctuating glycoform profile may reflect clonal fluctuation in relative levels of galactosyltransferase (Nishiura et al., 1990), or postsecretory degradation of N-linked oligosaccharides (Parekh et al., 1989), selection by different turnover rates among IgG molecules with different degrees of galactosylation (Newkirk et al., 1996), or altered microenvironments, particularly concerning cytokines released in inflammatory reactions (Hitsumoto et al., 1992) or in "immunization stress" (Bodman et al., 1994). These may be the 
underlying cause of the dominance of a particular glycoform at some time points during the response. On the other hand, there is evidence that the structure of the IgG molecule itself is an important parameter which affects the type of oligosaccharide attached, and the arm preference for galactosylation was seen to be related to the IgG subclass and, even, heavy chain allotypes in man (Jefferis et al., 1998). It is, therefore, possible that the fluctuations in IgG galactosylation during the immune response reflect the temporal distribution of isotypic or allotypic variants of anti-BSA antibodies galactosylated in a subclass/allotypespecific manner. Rabbits, however, unlike other mammalian species, which usually have several IgG subclasses, possess only one $\lg G$ isotypic variant (Nezlin, 1998). IgG-Fc carries two group e allotypes and the glycans are characterized by having a relatively high level of hypogalactosylated structures, approximately $35 \%$ G0 in the Fc region (Rademacher et al., 1996). In rabbit Fc, the opposing oligosaccharides in the $\mathrm{CH} 2$ domains possess different sequences and conformations (one of the $\alpha 1 \rightarrow 3$ arms is devoid of galactose, and the other can either be devoid of galactose or terminate in a single galactose residue), but only certain oligosacharides "fit together following the steric requirements of the protein-carbohydrate and carbohydrate-carbohydrate interactions within the $\mathrm{CH} 2$ domains" (Taniguchi et al., 1985). Whether or not e allotypes, which correlate with a Thr (e14) to Ala (e15) interchange at position 309 (Kehoe and Seide-Kehoe, 1979), which is near the attachment point for oligosaccharide, influence the local conformational changes and, thus, the G0-type structures is not clear. Murray and Brown (1988) found that conformational changes in the Fc region of autologous IgG occur during hyperimmunization of rabbits, which they suggested could be due to glycosylation pattern alterations, but serologic analyses performed to detect e and other allotypic markers during hyperimmunization, failed to reveal any alteration in preexisting allotypic expression. It may be, therefore, that the fluctuations in the degree of galactosylation that we observed in $\operatorname{lgG}$ of hyperimmune rabbits at different time points actually reflect intraclonal variations or the emergence of subclones of cells secreting IgG that is differently galactosylated from the IgG of nonimmunized animals. Variations were observed in the neutral oligosaccharide profile of IgG secreted by murine hybridomas (Rothman et al. 1989), as well as of individual lgG paraproteins at different stages of the disease in multiple myeloma in man, whilst that of the polyclonal IgG component remained stable (Farooq et al., 1997). This suggested that intraclonal changes of glycan composition may occur within the proliferative clone. However, in contrast to these non-physiological situations where the culture medium nutrients and $\mathrm{pH}$, proliferative state of the cells (malignancy) or other extreme conditions were identified as the sources of variability in glycosylation phenotype, galactose variations in $\mathrm{IgG}$ during the humoral response in immunized rabbits might be a part of the subtle, naturally occuring, transient alterations in carbohydrate structure, by which the glycans contribute to the different IgG-Fc effector functions within the single IgG isotype. It has been established that glycosylation of IgG-Fc is essential for recognition and activation of IgG-Fc receptors differently expressed on leucocytes (Jefferis et al 1998), and that conformation and effector activities of antibodies may be modulated by removal 
of particular sugar residues (Krapp et al., 2003). Since isotypic polymorphism of IgG (subclasses), which determines the effector potential(s) of IgG antibodies (Jefferis et al., 1998), does not exist in rabbits, glycosylation may be what defines functional subsets of isotypically uniform antibodies produced during an immune response in these animals.

The obtained results may be of particular interest since hyperimmune rabbits in our experiment have been shown to produce autoanti-IgG antibodies of the rheumatoid factor type reactive with anti-BSA antibodies (Milošević-Jovčić et al., 1995), and to develop arthritis. It has been shown that IgG with a decreased content of terminal galactose (GolgG) is a target for rheumatoid factor (Newkirk, 1996), which is the characteristic autoantibody associated with rheumatoid arthritis in man.

\section{ACKNOWLEDGEMENT:}

This work was supported by a Basic Science Grant from the Ministry of Science and Technology of Serbia.

Address for correspondence: Dragana Ćirić,

Institute for Medical Research,

Dr. Subotića 4, 11129 Belgrade,

Serbia \& Montenegro,

e-mail draganac@imi.bg.ac.yu

\section{REFERENCES}

1. Alavi A, Axford JS, 1996, The glycosyltransferases, In: Isenberg DA, Rademacher TW, editors, Abnormalities of IgG Glycosylation and Immunological Disorders, New York: John Wiley\&Sons, 149-69.

2. Bodman KB, Hutchings PR, Jeddi PA, Delves PJ, Rook GA, Sumar N, et al. 1996, IgG glycosylation in autoimmune-prone strains of mice. Clin Exp Immunpl, 95, 103-7.

3. De Vos-Cloetens Ch, Minsart-Baleriaux V, Urbain-Vansanten G, 1971, Possible relationship between antibodies and non-specific immunoglobulins simultaneously induced after antigenic stimulation. Immunology, 20, 955-62.

4. Farooq M, Takahashi N, Arrol H, Drayson M, Jefferis R, 1997, Glycosylation of polyclonal and paraprotein IgG in multiple myeloma. Glycoconj J, 14, 489-92.

5. Hitsumoto Y, Thompson ST, Zhang YW, Rook GAW, Elson CJ, 1992, Relationship between interleukin 6 , agalactosyl IgG and pristane-induced arthritis. Autoimmunity, 11, 247-54.

6. Jefferis R, Lund J, 1997, Glycosylation of antibody molecules: structural and functional significance. Chem Immunol, 65, 111-28.

7. Jefferis R, Lund J, Pound JD, 1998, IgG-FC-mediated effector functions: molecular definition of interaction sites for effector ligands and the role of glycosylation. Immunological Rev, 163, 5976.

8. Kehoe JM, Seide-kehoe R, 1979, Antigenic features of immunoglobulins, In:Attassi MZ, editor, Immunochemistry of proteins, New York: Plenum Press, 87-121.

9. Krapp S, Mimura Y, Jefferis R, Huber R, Sonderman P, 2003, Structural analysis of human IgG-Fc glycoforms reveals a correlation between glycosylation and structural integrity. $J \mathrm{Mol} B \mathrm{Biol}, 1-11$. 
10. Lastra GC, Thompson SJ, Lemonidis AS, Elson ChJ, 1998, Changes in the galactose content of IgG during humoral immune responses. Autoimmunity, 28, 25-30.

11. Masuda K, Yamaguchi Y, Kato K, Takahashi N, Shimada I, Arata Y, 2000, Pairing of oligosacharides in the Fc region of immunoglobulin G. FEBS Letters, 473, 349-57.

12. Milošević-Jovčić N, Tošić $L j$, Dovezenski N, 1995, Rheumatoid factors and circulating immune complexes in hyperimmunized rabbits. Acta Veterinaria, 45, 281-92.

13. Murray J, Brown JC, 1988, Hyperimmunization alters Fcy antigenicity. J Immunol, 141, 2668-73.

14. Nezlin R, 1998, The immunoglobulins, structure and function. San Diego-London: Academic Press.

15. Newkirk MM, Novick J, Stevenson MM, Fournier M-J, Apostolakos P, 1996a, Differential clearance of glycoforms of IgG in normal and autoimmune-prone mice. Clin Exp Immunol, 106, 259-64.

16. Newkirk MM, 1996b, Fc glycosylation and rheumatoid factors, In: Isenberg DA, Rademacher TW, editors, Abnormalities of IgG Glycosylation and Immunological Disorders, New York: John Wiley\&Sons, 119-30.

17. Nishiura T, Fujii Sh, Kanayama Y, Nishikawa A, Tomiyama Y, lida M, et al, 1990, Carbohydrate analysis of immunoglobulin $G$ myeloma proteins by lectin and high performance liquid chromatography: role of glycosyltransferases in the structures. Cancer Res, 50, 5345-50.

18. Parekh RB, Isenberg D, Rook G, Roitt I, Dwek RA, Rademacher T, 1989, A comparative analysis of disease-associated changes in the galactosylation of serum IgG. J Autoimmun, 2, 101-14.

19. Pilkington C, Wang Y, Rook GAW, 1996. The disease distribution and pathogenetic significance of a raised percentage of agalactosyl IgG, In: Isenberg DA, Rademacher TW, editors, Abnormalities of IgG Glycosylation and Immunological Disorders, New York: John Wiley\&Sons, 201-19.

20. Rademacher TW, Jaques A, Williams PhJ, 1996, The defining characteristics of immunoglobulin glycosylation, In: Isenberg DA, Rademacher TW, editors, Abnormalities of IgG Glycosylation and Immunological Disorders, New York: John Wiley\&Sons, 1-44.

21. Rook G, Thompson s, Buckley m, Elson Ch, Brealey R, Lmbert C, et al, 1991, The role of oil and agalactosyl IgG in the induction of arthritis in rodent models. Eur $\mathrm{J}$ Immunol, 21, 1027-32.

22. Rothman RJ, Warren L, Vliegenthart JFG, Härd KJ, 1989, Clonal analysis of the glycosylation of immunoglobulin $\mathrm{G}$ secreted by murine hybridomas. Biochemistry, 28, 1377-84.

23. Taniguchi T, Mizuochi t, Beale M, Dweek R, Rademacher TW, Kobata A, 1985, Structures of the sugar chains of rabbit immunoglobulin G: Occurence of asparagine-linked sugar chains in Fab fragment. Biochemistry, 24, 5551-57.

24. Thompson SJ, Leader KA, Lastra GC, Elson ChJ, 1996, The role of agalactosyl IgG in rodent models of autoimmune disease and in pathogenesis of rheumatoid arthritis, In: Isenberg DA, Rademacher TW, editors, Abnormalities of IgG Glycosylation and Immunological Disorders, New York: John Wiley\&Sons, 131-48.

25. Watson M, Rudd PM, Bland M, Dwek R, Axford JS, 1999, Sugar printing rheumatoid diseases. A potential method for disease differentiation using immunoglobulin $\mathrm{G}$ oligosaccharides. Arthritis Rheum, 42, 1682-90.

26. Wormald MR, Rudd PM, Harvey DJ, Chang S-Ch, Scragg IG, Dwek RA, 1997, Variations in oligosaccharide - Protein interactions in immunoglobulin $G$ determine the site-specific glycosylation profiles and modulate the dynamic motion of the Fc oligosaccharides. Biochemistry, 36, 1370-80.

27. Yamaguchi Y, Kato K, Shindo M, Aoki Sh, Aoki Sh, Furusho K, Koga K, et al., 1998, Dynamics of the carbohydrate chains attached to the Fc portion of immunoglobulin $G$ as studied by NMR spectroscopy assisted by selective ${ }^{13} \mathrm{C}$ labeling of the glycans. J Biomolecular NMR, 12, 38594.

28. Yuings A, Chang Su-Ch, Dwek R, Scragg IG, 1996, Site-specific glycosylation of human immunoglobulin $\mathrm{G}$ is altered in four rheumatoid arthritis patients. Biochem J, 314, 621-30. 


\title{
PROMENE U STEPENU GALAKTOZILACIJE IgG KUNIĆA TOKOM DUGOTRAJNE IMUNIZACIJE GOVEĐIM SERUMSKIM ALBUMINIMA
}

\author{
ĆIRIĆ DRAGANA i MILOŠEVIĆ-JOVČIĆ NADEŽDA
}

\begin{abstract}
SADRŽAJ
Ugljeni hidrati su strukturni element imunoglobulina $\mathrm{G}(\mathrm{IgG})$, bitan za konformaciju i efektorne funkcije molekula. Ugljenohidratni sadržaj čine oligosaharidni lanci (glikani) vezani kovalentno za konzervirani Asn 297 u svakom $\mathrm{CH} 2$ domenu Fc regiona IgG molekula. Sadržaj pojedinih šećera koji ulaze u sastav glikana nije isti u svim molekulima IgG. Imunoglobulini $\mathrm{G}$ su populacija različitih glikoformi čiji sadržaj varira pod fiziološkim, a naročito pod raznim patološkim uslovima. Predpostavlja se da su te varijacije odraz promena u distribuciji specifičnih antitela IgG klase tokom tekućeg, često hroničnog, imunog odgovora na neki antigen. O dinamici tih promena se, međutim, malo zna, a posebno o pojavi glikoformi tokom imunog odgovora koje bi mogle imati patogenetski značaj. U ovom radu su analizirane promene u glikozilaciji serumskih IgG tokom imunog odgovora kunića dugotrajno imunizovanih goveđim serumskim albuminima. Rezultati su ukazali da je taj odgovor praćen permanentnim promenama u sadržaju terminalne galaktoze. S obzirom da su molekuli IgG kunića, za razliku od drugih sisara, izotipski uniformni, tj. nemaju podklase (kojima je determinisana brojnost efektornih funkcija lgG), razlike u galaktozilaciji bi mogle determinisati pojavu funkcionalnih subsetova IgG antitela stvorenih tokom imunog odgovora kod ove vrste.
\end{abstract}

